\title{
THE EFFECT OF DUOLINGO ON THE WRITING COMPETENCY OF THE TENTH GRADE STUDENTS OF SMK N 1 SUKASADA IN ACADEMIC YEAR 2017/2018
}

\author{
N.L. Ivan Budiani ${ }^{1}$, L.P. Artini ${ }^{2}$, N.P. Astiti Pratiwi ${ }^{3}$ \\ ${ }^{123}$ English Language Education, Post Graduate Program, Universitas Pendidikan Ganesha, Singaraja \\ e-mail: niluhivanbudiani@gmail.com, putu.artini@undiksha.ac.id, astitipratiwi.eed@gmail.com
}

This study aimed at: 1) finding maxims of politeness principle expressed in Badung Regent Candidates Debate in 2015; 2) finding the most dominant maxim of politeness principle used in Badung Regent Candidates Debate in 2015. This study was designed mainly as a descriptive qualitative study which then supported by some descriptive quantification. The objects of the study were the utterances containing maxims of politeness principle expressed by the regent and vice regent candidates of Badung in Badung Regent Candidates Debate in 2015. The data were analyzed based on the theory of politeness principle proposed by Leech and the theory of categorization of speech act by Searle. The results of the study display that there are six maxims of politeness principle expressed in Badung Regent Candidates Debate in 2015 , namely the tact maxim, the generosity maxim, the approbation maxim, the modest maxim, the agreement maxim and the sympathy maxim. Furthermore, it is found out that the generosity maxim is the most dominant maxim used by the regent and vice regent candidates in Badung Regent Candidates Debate in 2015. The generosity maxim expressed in the debate applied the commissive type of speech act. Through the utterances of this maxim, they intend to convince the audience that they attempt to minimize benefit to self and maximize cost to self. The maxims expressed by the regent and vice regent candidates in the debate have a goal to communicate effectively

\section{Keywords: political debate, politeness principle, maxim, speech act}

\section{INTRODUCTION}

The 21st century learning has eventually transformed today's classroom (Santosa, 2017). Learning is no longer about listening to the teacher talk only. The 21 st century students are encouraged to gain new information through the problem they faced. Here, students-centered learning become the choice. The role of the teacher is as the facilitator in order to help the students in their learning. It happened because the globalization changed the educational system, but not the role of the education itself in order to prepare active and successful students. Students are supposed to have problem solving skill as well as critical thinking. They have to solve the problem by comparing the knowledge they have and the problem they face. They also learn how to collaborate themselves with the other students. Students are supposed to have higher order thinking skills in order to achieve those purposes. Those skills are important to prepare the generation to live in the 21st century (Collins, 2014). Here, Bloom's Taxonomy is one of the ways to teach higher order thinking skills to the students. The purpose of Bloom's Taxonomy is to promote the higher forms of thinking in education which include analyzing and evaluating, rather than just teaching students to remember facts (rote teaching) (Collins, 2014). Bloom's Taxonomy includes remembering, understanding, applying, analyzing, evaluating, and the last is creating. Students learn from the lowest one which is remembering till the highest which is creating.

Nowadays, the curriculum put more emphasis on the application itself. It means that students are expected to be able to apply what they have learned in the real situation. After they remember and understand, they have to apply what they have learned. One of the way is by doing communication, especially for the language learner. Communication becomes the essential part in their learning process. By communicating they will try to implement what they have learned in the classroom. In this case, communication consists of oral and written. In a very simple way it can be said that oral communication is a kind of communication which used spoken language to communicate whereas written communication used written media, such as magazine and newspaper. People commonly believe that written communication is 
harder than oral communication because writing is more complex. In fact, both written and oral form are equal. It is correlated with the statement from Thames (2016), he stated that becoming fluent in both writing and speaking English can take years, because English can be quite difficult to master due to its complexity.

One of the language which commonly used in the worldwide communication is English. English become one of the language which has the significant role in this globalization era. It is a global language or people called it as a lingua franca which more than 350 million people around the world speaking it as a first language and more than $\mathbf{4 3 0}$ million speaking it as the second language. (Wil, 2015). In line with the statement above, learning English become the essential matter to be done in this competition era. That is why English as Foreign Language $(E F L)$ is really needed to be learnt especially in facing the challenge in ASEAN Economic Community (AEC) which emphasizes on the human resources.

In Indonesia itself, EFL teaching still deal with problems. In Indonesia, the roles of English as international language, Indonesian government has decreed that English is one of the compulsory subjects from Junior high school to University. As a foreign language, English is rarely used outside the classroom context. Beyond the classroom, the Indonesian students speak Bahasa Indonesia or their local language. This condition affects the students' mastery in English (Suryanto, 2014). Students still found some difficulties in learning English. It is because the teaching and learning English in different countries still deals with some problems (Khajloo, 2013). Even they learned it for about some years but their English proficiency is still low. Listia and Kamal (2013) stated that the teachers still need to develop their competence in understanding the students' habit in learning the foreign language. Besides that, the lack of the learning sources and it also become one of the problem that the EFL learners faced. It becomes one of the most essential part to support the teaching and learning process. The used of learning sources and media can affect to the students' motivation as well. Vocabulary, pronunciation, and grammar are among the barriers for students to understand English. Brown (2000) stated that first language mastery may form one source of difficulty in learning second language. In Indonesia, most students start studying English at junior high schools or around 12-year-old of age and they have already possessed in their mind. Moedjito and Harumi (2008) have conducted a research about an investigation of the mispronunciation of English sounds by Indonesian English learners. The results of this study indicated that the Indonesia learners who already possessed their first language pronunciation often confused when they learn English pronunciation system. This is also supported by Tantra (2015) stated that the level of proficiency in the first language has direct influence on the development of proficiency in the second language.

Writing is an essential skill that needs to be acquired by students and also part of EFL issues and challenges in Indonesia. Moedjito and Harumi (2008) found that mother language is still dominant among Indonesia learners. Those problems could affect the students' knowledge of grammatical structures and vocabulary mastery. Students still have difficulties in mastering writing. It is quite difficult for students to master it, since there are gaps between Bahasa Indonesia and English in terms of structure and styles. Moreover, students' ability to translate and transform meaning from Bahasa Indonesia to English context seems awkward and not make sense when it is read by people especially English native speakers (Ariyanti, 2016). In Indonesia, the time for English class is very short, it just about once or twice in a week and each meeting often occurred for about one or two hours. Besides of that, every day are contained with lots of subject matter to learn and it can make the teacher often fail to reach the objectives that have been set and the teacher cannot recognize the problems that is happen in the learning process. As stated by Putra (2015), schools more concentrate English on subject rather than on proficiency level which shows a failure in language solely purpose. He also stated that high score obtained in semester report means that students are able to comprehend English merely in theory.

The government has recently introduced the new curriculum called Curriculum 2013. Curriculum 2013 is designed in anticipation to modern learning in the twentieth century (Tantra, 2015). In this new curriculum, teachers are required to have some competencies in order to apply this curriculum. They are also supposed to be able to develop the materials to make it suitable with the teaching goals. In line with that, the teachers have to choose the 
right strategy and method that they are going to implement in the classroom. According to Harmer (1998) and Richard (2001) in Andariyani and Nurhajati (2016), English teachers should have competencies to develop and adapt the materials based on the students' need and ability by modifying the content and task. In line with that statement, teachers also have to choose a good technique to support their materials in order to make students interest. This also will help in building the students' motivation in learning.

Technology has a big impact to our life whether it is positive or negative. One of the positive impacts which can be seen is on the educational area. Technology supports the educational system in order to make the students easier in their learning process. From that, it can be seen that technology and education has a deep relationship. According to Klopfer, Osterweil, Groff, and Haas (2009), the emergence of new technologies pushes educator to understanding and leveraging these technologies for classroom used; at the same time, the on-the-ground implementation of these technologies in the classroom can (and does) directly give impact to how these technologies continue to take shape. For that reasons, teachers should be able to implement the technology in their classroom section. Technology takes a very important role in helping students to learn language. The development of technology is always rapid time by time. Almost every people in this world have their own devices as well social media to help them in their daily life. It makes them easier in doing communication with others. Besides for communicating, technology also can be used to help students for their learning.

Nowadays, technology based learning has become one of the highly recommended in the process standard of curriculum 2013. In the curriculum 2013 especially in Permendikbud no. 22 Tahun 2016 stated that there are some standards which should be fulfill by the teacher. One of those standards is the use of the information communication technology (ICT) in order to improve the efficiency and effectivity in the learning process. This is the reason why technology is needed to be developed in the school. In the world of technology, there is a term called as Electronic Learning which commonly known with its abbreviation 'E-Learning'. Agaev and Mamedova (2017) stated that E-learning constitutes a significant competition to traditional education in many countries and has become a major tool for the modernization of education and economic growth. In addition, they also argued, for the development and implementation of successful E-Learning system, we need technologies that allow working with them for any number of users, providing a good learning environment. E-Learning makes education more accessible in that it enables learners to find source of information regarding to their own problem or task that is difficult to find in the printed media sources. Some of the schools is already implemented E-Learning in the school.

In secondary school nowadays especially those which located in urban area, it is common that students possessed a smartphone. A study which was conducted by Dewanti, Widada, and Triyono (2016) found that there is a relation between students' achievement and the use of smartphone in the school. They found that smartphone help the students with their study. In another phenomenon, students can use their smartphone as the tool for sharing information and to access their social media like twitter and Facebook (Firmana, 2016). In his study, Firmana (2016) also found that the students' ownership of smartphone is very high. This actually the advantages for teaching and learning because it can be used to support technology based learning in the classroom. In fact, the knowledge of function of smartphone in education is still minimum. As stated in Firmana (2016) about the use of smartphone by students, seems that the students did not maximize the use of their smartphone in educational purposes yet. Actually, there are some secondary schools in Bali especially in Singaraja which already implemented E-Learning in the school. One of them is SMK N 1 Sukasada. In this school, students are allowed to bring their own smartphone. Hence, there is a lack of understanding of the effective smartphone usage for educational purposes in the students' mind, because the implementation of E-Learning is categorized as new system since it started in 2018.

In exploring the empirical evidence about the use of technology in teaching, the researcher found a number of research while the most is work on research and development in which the purpose was to develop materials. There has not been much research found in investigating the impact on teaching English as a foreign language in more particular the 
impact on writing. There is very limited research has been found that specifically experiment the use of technology based instruction. For this reason, the researcher attempt to do a research in SMK N 1 Sukasada to investigate the impact of technology based instruction in the form of game based learning which is called Duolingo. Duolingo is a kind of premium language-learning platform. This application is available on iOS, Android, Windows and another platform. It is an application which was launched in 2012 which allow the user for learning English for free. Duolingo is one of language learning application which contains all aspects in writing. It will help students in their grammar, translation, vocabulary and spelling. For this reason, this study will be focused on the students writing competency because there is very limited research has been found that specifically experiment the use of technology based instruction, especially for writing purposes.

Some studies were also conducted in other country in order to know the effectiveness of this application. Vesselinov and Grego (2012) conducted a study which the purpose was to investigate the effectiveness of this application. The result of the study found that Duolingo is effective to help the college students to learn Spanish. Another study about the use of Duolingo to learn Spanish was also conducted by Munday (2016) in order to investigate whether Duolingo is easy and effective application to use or not. In line with the previous study, the result of this study also showed that Duolingo is an easy, helpful, and enjoyable application to learn Spanish. Another study about Duolingo was also conducted by Garcia (2013) which focused on the use of Duolingo for learning English. This study found that Duolingo focused on reading, listening, writing and speaking, and it is effective for learning English. Based on some studies above, it can be seen that Duolingo is a kind application which is effective to learn a new language. Because of this reason, the researcher attempt to do a research which focused on the use of Duolingo in the school in order to see the impact on the students' writing competency. This study was conducted because in Bali especially in Singaraja there has not been a research about the use of Duolingo in school.

Reviewing from previous literature and existing research about the implementation of Duolingo in language learning, it is obtained that Duolingo could help students to mastered new language in an interesting and in easy way. Munday (2016) also conducted a study about the implementation of Duolingo in learning Spanish which showed that Duolingo is an easy, helpful, and enjoyable app to practice Spanish. Besides, Vesselinov and Grego (2012) also conducted a research to find out the effectiveness of Duolingo. The purpose of this study is to evaluate the effectiveness of this application. This research was funded by Duolingo, but for the research itself done by the researcher. The result of the research showed that Duolingo is effective. In this study the previous researcher conducted his study through some college students who learned Spanish by using Duolingo. The researcher wants to use this study as the comparison for conducting a similar study in the different area to the different subject of the study.

From the reason above, the researcher interested to implement Duolingo and find out the effect on the students' writing competency in SMK N 1 Sukasada. Writing competency is chosen because writing is one of the essential skill that is needed in the learning process, and writing is also a productive skill. Duolingo is chosen because this app emphasized more in the enrichment of vocabulary and grammatical structure which is very needed to improve students' writing competency. The other reason is because research about the implementation of Duolingo has not been conducted yet in Bali especially Singaraja

\section{RESEARCH METHOD}

The design of this study was a quasi-experimental research. This study purposed to investigate whether or not there was a significant effect of the implementation of Duolingo on the students' writing competency of the tenth grade students in SMK N 1 Sukasada in academic year 2017/2018. This study used Post-Test Only Control Group Design. According to Fraenkle and Wallen (1993), Post-Test Only Control Group Design involves two groups which are formed by random assignment. There were two groups in this design, namely: control group and experimental group. Experimental group was the group which was taught by using Duolingo. Meanwhile control group was the group who was taught by using conventional strategy. The preliminary research conducted to verify the data which had been 
gained like data of the latest writing scores. The latest writing score of both groups collected to determine the normality and homogeneity of the population. The data of both groups were tested by using SPSS. 16.0. to confirm the data were homogenous and in normal distribution. After conducting normality and homogeneity test of variances, the data were tested using independent sample test (t-test). It proposed to make sure the data obtained in the same average of level of intelligence and the data were precise to be used in this study. After that, Duolingo was implemented in the experimental group. After the implementation of Duolingo, the post-test was conducted on the two group to get the result. The results of the post-test were compared to find out whether Duolingo gave significant effect on the students' writing competency or not.

This study used cluster random sampling as the sampling technique. The lottery administered for determining the sample. In this case, the researcher applied the lottery to randomly choose 2 classes as the samples of this study. Furthermore, the second lottery conducted to determine which class that was treated as experimental group and one which became the control group. As the result, X AP 1 and X AP 2 were determined as the samples of this study. There were 35 students in class X AP 1 which consisted of 18 males and 17 females. Then, there were also 35 students in class X AP 2 which consisted of 18 males and 17 females.

The data were collected by using post-test for both groups. The post-test was given after doing the treatment to know whether or not there was any significant effect of the implementation of Duolingo on students' writing competency.

The procedures of data collection of this study were listed as follows:

1. Choosing the population of the study.

2. Determining two groups as the sample of the study by using cluster random sampling.

3. Measuring the normality and homogeneity of variance of the sample.

4. Testing the homogenous data by using independent sample T-test.

5. Making the decision of the experimental and control group as the sample by lottery.

6. Doing preparation for the research instruments.

7. Judging the research instruments with the expert judges.

8. The experimental group are taught by using Duolingo and the control group are taught without Duolingo or conventionally.

9. Administering the post-test to both groups after the end of the treatment

10. Examining the result of the post-test by using descriptive and inferential statistical analysis to make the conclusion of the study.

11. Concluding the result of the study

\section{FINDINGS AND DISCUSSION}

These findings cover the result of normality and homogeneity test and the result of the posttest. The discussion presents the description of inventions and result of this study related to the theory concerned. The findings contain the data analysis which contain the descriptive statistic and the inferential statistic.

In this study the descriptive statistical consist of mean, median, mode, range, variance, and standard deviation. The data were analyzed by using SPSS 16.0. The data could be seen as follows.

Table 1. Descriptive statistical findings

\begin{tabular}{lcc}
\hline & Experimental Group & Control Group \\
\hline Mean & 80.69 & 71.97 \\
Median & 83.00 & 70.00 \\
Mode & 75 & 70 \\
Std. Deviation & 9.145 & 12.176 \\
Variance & 83.634 & 148.264
\end{tabular}

Jurnal Pendidikan Bahasa Inggris Indonesia | 25 


\section{$\begin{array}{lll}\text { Range } & 30 & 43\end{array}$}

The table above shows the result of the central tendency measurement and dispersion measurement.

1. Mean

From the table above, it can be seen that the mean score of both group were different. The mean score of the experimental group was 80.69 , meanwhile the mean score of the control group was 71.97

2. Median

The data showed that the median of the experimental group's score was 83.00. Meanwhile, the median of the control was 70.00.

3. Mode

The mode of the score of the experimental group was 75 . However, the mode of the control group was 70 .

4. Standard Deviation

The data above showed that the standard deviation of the experimental group was 9.145 whereas the control group was 12.176 of the standard deviation.

5. Variance

Variance is the amount of spread among score. The table above presented the variance of the experimental group was 83.634 and the variance of the control group was 148.264 .

6. Range

The range of the experimental group was 30 as the difference between the maximum score was 96 and the minimum score was 66. Moreover, the range of control group was 43 which showed from the difference between the maximum score of 93 and the minimum score of 50 .

The inferential analysis provided the data which gained from the posttest calculated inferentially through t-test. T-test aimed at determining whether or not the treatment of implementing Duolingo contributed the significant effect on the tenth grade students' writing competency. Beforehand, the researcher had to measure the normality and homogeneity of the data by using SPSS 16.0 in order to make sure whether or not the data were in normal distribution and homogeneous.

Before conducting the t-test, the test of normality was conducted in order to know the normality of the data gained. In this study, the researcher used the Kolmogorov-Smirnov statistic by using SPSS 16.0. Considering the result of the normality test, the KolmogorovSmirnov statistic was required to be higher than the significance value of .05 which to be assumed that the data was in normal distribution. The result of the normality test of the variance using SPSS can be seen on the following table.

Table 2. Finding of Tests of Normality

\begin{tabular}{clcccccc}
\hline & \multirow{2}{*}{ Kelompok } & \multicolumn{3}{c}{$\begin{array}{c}\text { Kolmogorov- } \\
\text { Smirnova }\end{array}$} & \multicolumn{3}{c}{ Shapiro-Wilk } \\
\cline { 3 - 8 } & & Statistic & Df & Sig. & Statistic & df & Sig. \\
\hline \multirow{2}{*}{ Nilai } & Experiment & .122 & 35 & $.200^{*}$ & .946 & 35 & .085 \\
& Control & .085 & 35 & $.200^{*}$ & .969 & 35 & .413 \\
\hline
\end{tabular}

The table above shows that the significance value of both experimental and control group were beyond the significant value (Sig.) of .05 which based on Kolmogorov-Smirnova column. The significance value reached by experimental group was .200 and the control group gained .200. Those result indicated the data gained in this study was in normal distribution. Hence, the data passed the requirement of proceeding t-test. Nonetheless, before the data directly conducted the t-test, the data had to measure the homogeneity of the variance as the other prerequisite of conducting t-test.

In order to test the homogeneity of variance of the data, Levene's statistic test was used. Jurnal Pendidikan Bahasa Inggris Indonesia | 26 
The data considered as homogeneous data if the data exceeded the significance value of .05 $(5 \%)$. The result of homogeneity test of variance can be seen as follows.

Table 3. Finding of Test of Homogeneity of Variance

\begin{tabular}{llcccc}
\hline & Levene Statistic & df1 & df2 & Sig. \\
\hline Nilai & 2.716 & 1 & 68 & .104 \\
$\begin{array}{l}\text { Based on Mean } \\
\begin{array}{l}\text { Based on Median } \\
\text { with adjusted df }\end{array}\end{array}$ & 2.192 & 1 & 68 & .143 \\
$\begin{array}{l}\text { Based on trimmed } \\
\text { mean }\end{array}$ & 2.192 & 1 & 60.308 & .144 \\
\hline
\end{tabular}

The table above shows the result of homogeneity test. The significance of each group was beyond the significance value of $.05(5 \%)$. The significance value based on mean was .104 , based on median .143, based on median and with adjusted degree of freedom was .144 , as well as based on trimmed mean was .103. As the result above, experimental and control group were characterized as homogenous variance. Due to the data passed the requirement of conducting t-test which the value was higher than the level of significance, the t-test could be proceeded to measure whether the implementation of Duolingo gives a significant effect on the tenth grade students' writing competency of SMK N 1 Sukasada.

In this study, in advance of conducting hypothesis testing, the data were measured to investigate the data were normally distributed and homogeneous in terms of variance. After that, the researcher conducted the t-test in order to draw a conclusion whether or not the implementation of Duolingo had a significant effect on the tenth grade students' writing competency of SMK N 1 Sukasada. The result of the t-test as follows.

Table 4. Results of Independent Samples Test

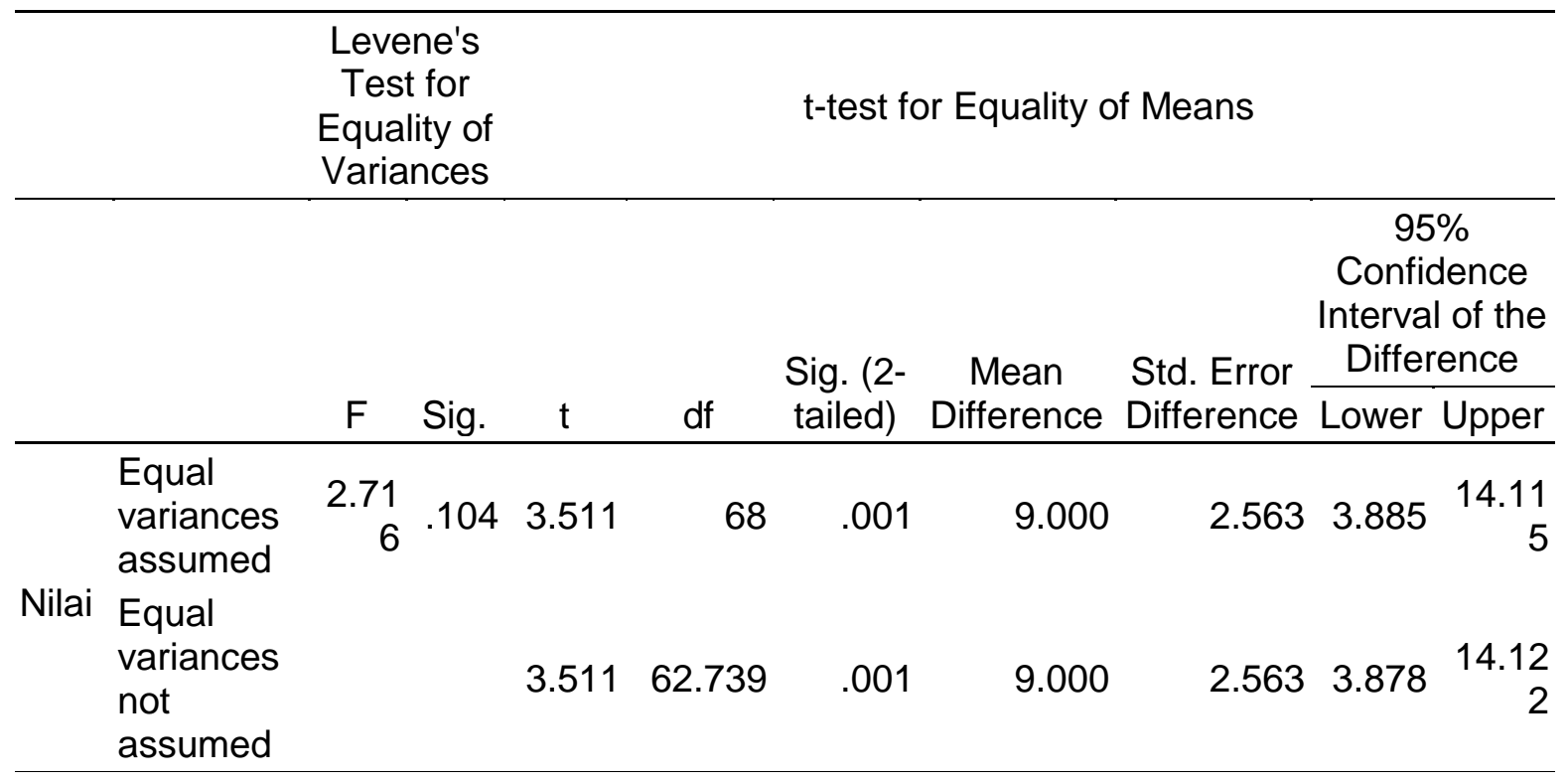

Based on the table above, the data had coefficient $F 2.716$ with the significance value (Sig.) .104 that was higher than .05 (5\%) indicated the samples were homogeneous. Since the samples were homogenous, the result of the hypothesis can be seen from the "equal variances assumed'. Henceforward, tobs of the data was 3.511 and it surpassed the value of the tcv since the researcher determined the tcv for degree of freedom (df) 68 was 1.990 ( $\alpha=$ 0.05). The comparison between tobs and tcv was $3.511>1.990$ which inferred that the alternative hypothesis $(\mathrm{Ha})$ was accepted. Further, it can be supposed to be there is a significant effect of the implementation of Duolingo on students' writing competency of the 
tenth grade students of SMK N 1 Sukasada.

It was also very interesting to know for the detail indication that Duolingo had a better impact for the students' writing competency. Thus, the table below would show the comparison of the score gained between both groups in the components of writing.

Table 5. Students Writing Achievement

\begin{tabular}{clcccc}
\hline No & $\begin{array}{c}\text { Component of } \\
\text { Writing } \\
\text { Assessed }\end{array}$ & $\begin{array}{c}\text { Total Score of } \\
\text { Experimental } \\
\text { Group }\end{array}$ & Mean Score & $\begin{array}{c}\text { Total Score of } \\
\text { Control Group }\end{array}$ & $\begin{array}{c}\text { Mean } \\
\text { Score }\end{array}$ \\
\hline 1 & Content & 123 & 3.5 & 109 & 3.1 \\
2 & Organization & 120 & 3.4 & 97 & 2.8 \\
3 & Grammar & 101 & 2.9 & 92 & 2.6 \\
4 & Vocabulary & 105 & 3.0 & 91 & 2.6 \\
5 & Mechanics & 104 & 3.0 & 108 & 3.1 \\
\hline
\end{tabular}

From table above, it can be seen the comparison score gained by the students in experimental group and control group in the components of writing. The total score of content gained by the experimental group was 123, meanwhile in the control group was 109. The range between the score of both group was 14 score. The score of experimental group was higher than the control group. It also happened on the other component such as organization, grammar, and vocabulary. The score of the experimental group was higher. From those result, it can be concluded that Duolingo was effective in order to help the students to improve their writing achievements. This was supported by Garcia (2013) which also conducted the study about the Duolingo as a media of learning which was found that Duolingo was effective. The other study conducted by Castro (2016) also found the improvement of the students' achievement in grammar and vocabulary during the implementation of Duolingo on his study.

Meanwhile in the mechanic component, the score of the control group was higher. In Duolingo, the students learned to translate the sentence by choosing the words given or by typing the words. But, in this application the mechanic system was not available. The students did not practice how to use punctuation, capitalization. This also became the disadvantages of using this application. The students could not learn how to use punctuation as well as capitalization.

In the previous discussion, the analysis of the students' writing competency showed that Duolingo gave significant effect toward students' writing achievement. When the result of post-test was compared with the students last writing which was given by the teacher, there was also an improvement of the students' score. Students' last mean score in experimental group was 72.05. After the treatment was conducted in the experimental group, the mean score was 80.69. It showed statistically that Duolingo can encourage the students to gain higher score. In conclusion, Duolingo could give significant effect toward the students to improve their writing performance.

The significant effect of the use of Duolingo had been proved by the statistically. Moreover, it would be stronger by the support of qualitative data. Qualitative data was conducted by giving questionnaire. The questionnaire was given in order to know the students' response toward the implementation of Duolingo. The students' response would support the result of the quantitative data.

From the students' response toward questionnaire, it was found that the improvement of the writing performance was also felt by the students. It could be seen from the students' response toward items of the statement in the questionnaire. From item (No. 8) "I believed that Duolingo helped me to increase my writing competency in English", 42.9\% students stated strongly agree, $42.9 \%$ stated agree, $11.4 \%$ stated neutral, and only $2.9 \%$ stated less agree. From that, it indicated that most students realized that Duolingo could help them in increasing their writing competency.

The improvement of the students' writing competency was because the students were easily in understanding the material. It can be seen from (item 5) "Duolingo helped me to 
understand the material" which $40.0 \%$ students stated strongly agree, $48.6 \%$ students stated agree, $8.6 \%$ neutral, and only $2.9 \%$ stated less agree. It meant that the students did not find any significant difficulties in in their learning. According to Castro (2016), this is because Duolingo help the students to increase vocabulary and better development of simple grammatical structures. Castro (2016) also stated that we can see significant improvement in the performance of all students, without exceptions. Besides that, the students also felt more motivated in their study. It can be seen from item 4 which stated that "I felt more motivated when studied English by using Duolingo" which most students stated strongly agree (42.9\%), agree $(48.6 \%)$, and neutral $(8.6 \%)$. It meant that the students also felt the effect of the implementation of Duolingo could motivate them in English learning.

On the other hand, the students' feeling about Duolingo was also need to be known. It can be seen from item (No. 1) "I like to study by using Duolingo" which the most of the students stated strongly agree $(62.9 \%)$, agree $(28.6 \%)$, and the rest were neutral $(8.6 \%)$. From that, it can be seen that the students like to use Duolingo. It was because Duolingo was very simple and easy to use. It made the students comfortable in using this application in the classroom. As stated by Castro (2016) that Duolingo works in a very simple way. This was also supported by item (No. 2) and item (No.3) which "I enjoyed to study English by using Duolingo" which the most students stated strongly agree (51.4\%), agree (40.0\%), and neutral $(8.6 \%)$ and "I like if my teacher used Duolingo while teaching in the classroom" which most of the students stated strongly agree (68.6\%), agree (25.7\%), and neutral (5.7\%). Based on Castro et al (2015), using application can give benefit for the teacher so the teacher can effective in his pedagogical practice the use of technologies and the advantages obtained with this practice.

Besides the students' belief and feeling, Duolingo also affected the students' behavior and attitude like stated in item (No. 6) "I used Duolingo when I studied independently outside the classroom" which most of the students stated strongly agree $(22.9 \%)$, agree $(48.6 \%)$, neutral (28.6\%). Because Duolingo was the application which students could install in their phone, it became easy to use it anytime inside or outside the classroom. Because they used it often even out of the school, they became confident to use this application. It supported by item (No. 9) "I felt confident in using Duolingo) which most students stated strongly agree $(22.9 \%)$, agree $(48.6 \%)$, neutral $(25.7 \%)$, and less agree $(2.9 \%)$. Because of the good effect that the students felt and believed, they also add that the use of Duolingo in the school was very important. Supported by item (No. 10) "I believed that the use of Duolingo in the school is very important) which most students stated strongly agree (31.4\%), agree (45.7\%), neutral $(22.9 \%)$.

Based on the result of the questionnaire, the students showed positive response toward the use of Duolingo. In line with that, Munday (2016) was also conducted a survey about the use of Duolingo as the complement in learning Spanish as second language. The result of this study also showed that Duolingo was an easy, helpful, and enjoyable app to practice Spanish. The positive response that students showed toward questionnaire was also in line with the quantitative data of this study. The quantitative data of this study showed that students gained high score after having the treatment. The analysis of questionnaire also showed that the students' response toward the improvement of their writing was positive. Besides, the application of Duolingo in the classroom was also responded positively by the students. In conclusion, the significant effect of the implementation of Duolingo in this study had been proved quantitatively and qualitatively.

\section{CONCLUSION}

This experimental study conducted to examine the significance effect of the implementation of Duolingo on the students' writing competency of the tenth grade students of SMK N 1 Sukasada in academic year 2017/2018. Based on the findings, it can be summarized that the experimental group achieved better achievement rather than control group. Hence, the research findings proved that the use of Duolingo as teaching media is effective to assist the students to improve their writing competency. Additionally, it was proven that the use Duolingo as teaching media in English language learning brought significant effect on the students' writing competency compared to the conventional teaching 
media. To sum, the implementation of Duolingo has a significant effect to the students' writing competency. In line with this statement, the hypothesis of "there is a significant effect of the implementation of Duolingo on the writing competency of the tenth grade students of SMK N 1 Sukasada in academic year 2017/2018." is accepted.

\section{REFERENCES}

Andariyani, N., \& Nurhajati, D. (2016). The Implementation of Teaching English Based On Curriculum. Journal of English Teaching and Research, 1(2), 79-87. Retrieved from https://www.google.com/url?sa=t\&rct=i\&q=\&esrc=s\&source=web\&cd=1\&cad=rja\&uact= 8\&ved=0ahUKEwj3vJ63qP bAhURd94KHZ-

9AzoQFggaMAA\&url=http\%3A\%2F\%2Fkuisioner.lp2m.unpkediri.ac.id\%2Findex.php\%2 Finggris\%2Farticle\%2Fdownload\%2F480\%2F371\%2F\&usg=AOvVaw2aP7KN9h9B8k9LUPH4-26

Brown, H. D. (2000). Principle of Language Learning and Teaching. White Plains, New York: Addison Wesley Longman, Inc.

Collins, R. (2014). Skills for the 21st Century: teaching higher-order thinking. Curriculum \& Leadership Journal, 12(14). Retrieved from: http://www.curriculum.edu.au/leader/teaching higher order thinking,37431.html?issuel $\underline{D}=12910$

Castro, A. P., Macedo, S. H., \& Bastos, H. P. (2016). Duolingo: An Experience in English Teaching. Journal of Educational and Instructional Studies in the World, 6(4), 5963.

Dewanti, T. C., Widada, \& Triyono. (2016). Hubungan Keterampilan Sosial dan Penggunaan Gadget Smartphone dengan Prestasi Belajar Siswa SMA Negeri 9 Malang. Jurnal Kajian Bimbingan dan Konseling, 1(3), 126-131.

Firmana, Y. D. (2016). Penggunaan dan Pemanfaatan Smartphone di Kalangan Siswa Kelas X Studi Kasus: SMA Negeri 3 Pati Kelas X MIA-6 (Bachelor's Thesis, Universitas Kristen Satya Wacana, Salatiga). Retrieved from: http://repository.uksw.edu/bitstream/123456789/10690/2/T1 702010140 Full\%20text.p df

Garcia, I. (2013). Learning a Language for Free While Translating the Web. Does Duolingo Work? International Journal of English Linguistics Vol. 3, 19-25. Retrieved from: http://www.ccsenet.org/journal/index.php/ijel/article/viewFile/24236/15350

Khajloo, A. I. (2013). Problems in Teaching and Learning English for Students. International Journal of Engineering Research and Development, 7(3), 56-58. Retrieved from: http://www.ijerd.com/paper/vol7-issue3/10703056058.pdf

Klopfer. E, Osterweil, S., Groff, J., \& Haas, J. (2009). The Instructional Power of Digital Games Social Networking Simulations and How Teachers Can Leverage Them. Massachusetts: The Education Arcade.

Listia, R., \& Kamal, S. (2013). Kendala pengajaran bahasa Inggris di sekolah dasar (problems of English teaching in elementary school). Jurnal Bahasa Dan Sastra, 3(2), 244-251.

Moedjito, \& Harumi, I. (2008). Perceptions of the Seriousness of Mispronunciations of English Speech Sounds. TEFLIN Journal, 19(1). Retrieved From: http://journal.teflin.org/index.php/journal/article/download/98/92

Munday, P. (2016). The case for using DUOLINGO as part of the language classroom experience. RIED. Revista Iberoamericana de Educación a Distancia, 19(1), 83101. Retrieved from: http://revistas.uned.es/index.php/ried/article/download/14581/13569

Santosa, M. H. (2017). Learning approaches of Indonesian EFL Gen Z students in a Flipped Learning context. Journal on English as a Foreign Language, 7(2), 183-208. 